\title{
Fungsi Date dalam Data Manipulation Language Dengan Bahasa Query Menggunakan SQL Server 2008
}

\author{
Didik Setiyadi ${ }^{1}$, Henderi², Rita Wahyuni Arifin ${ }^{3}$ \\ 1Teknik Informatika; Universitas Bina Insani; Jl. Siliwangi No.6 Rawa Panjang Bekasi Timur \\ 17114 Indonesia; Telp. (021) 82436 886, Fax. (021) 824009 24; \\ e-mail: didiksetiyadi@binainsani.ac.id \\ 2Teknik Informatika; Universitas Raharja; Jl.Jend.Sudirman No.40 Cikokol Kota Tangerang \\ 15117 Indonesia; Telp. (021) 55749539, email: henderi@raharja.info \\ ${ }^{3}$ Manajemen Informatika; Universitas Bina Insani; Jl. Siliwangi No.6 Rawa Panjang Bekasi \\ Timur 17114 Indonesia; Telp. (021) 82436 886, Fax. (021) 824009 24; \\ e-mail: ritawahyuni@binainsani.ac.id \\ * Korespondensi: e-mail: didiksetiyadi@binainsani.ac.id
}

Diterima: 5 Mei 2020; Review: 10 Mei 2020; Disetujui: 29 Mei 2020;

Cara sitasi: Setiyadi D, Henderi, Arifin RW. 2020. Fungsi Date dalam Data Manipulation Language Menggunakan Bahasa Query dengan SQL Server 2008. Informatics for Educators and Professionals. Vol 4 (2): 163-172.

\begin{abstract}
Abstrak: Fungsi date dalam melakukan manipulasi data dengan bahasa query merupakan fungsi yang diperuntukkan bagi data, variable atau field yang berkaitan dengan data tanggal dan dapat pula diterapkan untuk data dari tanggal sistem komputer yang sedang aktif. Fungsi tanggal dalam SQL (Structured Query Language) meliputi fungsi DateAdd, Datelff, DatePart, DateName dan GetDate. Data Manipulation Language (DML) merupakan bahasa basis data yang berfungsi untuk melakukan penelusuran data pada suatu basis data didalam DBMS (Database Management System) diantaranya melakukan insert data, delete data, update data dan penelurusan data (query). SQL (Structured Query Language) terdiri dari sintaks sederhana dalam bentuk instruksi-instruksi dalam melakukan manipulasi data, instruksi tersebut sering disebut dengan query. Sedangkan untuk proses query merupakan kemampuan untuk melakukan penelusuran data dari basis data, data yang ditampilkan bisa dari satu atau lebih tabel, dimana kolom-kolom yang dipilih bisa kita tentukan sendiri. Pada penulisan ini akan dibahas tentang bagaimana melakukan operasi query untuk fungsi date dengan menggunakan SQL Server 2008. Langkah awal yang dilakukan adalah dengan mengambil studi kasus database Nilai Mahasiswa yang telah terbentuk diagrammnya beserta isi datanya. Selanjutnya bagaimana melakukan operasi dengan menggunakan fungsi DateAdd, Datelff, DatePart, DateName dan GetDate untuk melakukan penelusuran data dengan menggunakan DBMS SQL Server 2008.
\end{abstract}

Kata Kunci: Fungsi date, DML, Query, Sql Server 2008, Nilai Mahasiswa.

Abstract: The date function in manipulating data with the query language is a function that is
intended for data, variables or fields relating to date data and can also be applied to data from
the date of an active computer system. Date functions in SQL (Structured Query Language)
include DateAdd, Datelff, DatePart, DateName and GetDate functions. Data Manipulation
Language (DML) is a database language that functions to search data in a database in a DBMS
(Database Management System) including inserting data, deleting data, updating data and
searching data (query). SQL (Structured Query Language) consists of simple syntax in the form
of instructions in manipulating data, these instructions are often called queries. As for the query
process, it is the ability to search data from a database, the data displayed can be from one or
more tables, where the columns we choose can be determined by us. At this writing will be
discussed about how to perform a query operation for the date function using SQL Server 2008 .
The initial step is to take a case study of the Student Value database that has been formed 
diagramm along with the contents of the data. Next how to perform operations using the DateAdd, Datelff, DatePart, DateName and GetDate functions to perform data tracing using SQL Server 2008 DBMS.

Keywords: Date function, DML, Query, SqI Server 2008, Student Value.

\section{Pendahuluan}

Sistem basis data merupakan bagian dari sistem informasi didalam suatu perusahaan, baik pada sekala kecil, menengah maupun besar. Didalamnya juga meliputi sumber daya yang dilibatkan dalam melakukan koleksi, manajemen, penggunaan dan disseminasi sumber daya informasi. Sedangkan pada sistem komputerisasi, sumber daya merupakan data, perangkat lunak Database Management System (DBMS), perangkat keras komputer, media penyimpanan, orang yang menggunakan dan mengatur data (database administrator, pemakai akhir, dan user dan lainnya), perangkat lunak aplikasi yang mengakses dan melakukan perubahan data, serta programmer aplikasi yang membuat program aplikasi [1].

Berdasarkan hasil penelitian dan pengujian pada 30 kalimat perintah yang terdiri 6 (enam) kombinasi pada query diperoleh akurasi $82,35 \%$. Kesalahan yang terjadi diakibatkan belum tertanganinya kalimat pencarian tanggal dan juga sub-query dengan lebih dari dua tabel dan sub-query dengan jenis nested query. Permasalahn tersebut dapat ditangani dengan menambahkan aturan-aturan pendeteksi nested subquery dan menambahkan pendeteksian tanggal dalam proses pencarian [2].

Database Mangement System (DBMS) adalah koleksi terpadu dari aplikasi program (system software) yang dapat digunakan dalam melakukan definisi, membuat, melakukan akses dan memelihara database [3]. Sedangkan Relational Database Management System (RDBMS merupakan aplikasi database yang menggunakan prinsip relational dimana antar tabel-tabel saling terintegrasi [4]. Basis data merupakan koleksi terpadu dari data yang tersimpan dalam tabel-tabel yang saling terintegrasi dengan tujuan untuk memenuhi kebutuhan user dalam pengambilan kembali data untuk menghasilkan informasi yang dibutuhkan [3].

Microsoft SQL Server merupakan perangkat lunak RDBMS kelompok enterprise yang sering dimanfaatkan di perusahaan korporasi. Dengan menggunakan dan memanfaatkan SQL server user dapat dapat melakukan penyimpanan kelompok data dan mengimplementasikannya untuk kegiatan bisnis dalam dunia usaha dan industri [5]. Arsitektur dalam Microsoft SQL Server 2008 adalah client/server yang merupakan software RDBMS yang sangat handal yang didesain dalam mendukung transaksi yang kompleks [6]. Dalam mengakses relasional database, kita harus mengenal sintaks-sintaks dalam SQL (Structured Query Language) yang dapat mendukung SQL sebagai bahasa dalam memproses query ke dalam database. Pada microsoft SQL Server juga banyak digunakan pada dunia usaha dan bisnis, education maupun lembaga pemerintah sebagai solusi dalam membangun database atau penyimpanan data [7].

Sintaks dalam SQL adalah perintah dalam melakukan pengolahan, menampilkan dan memanipulasi data yang tersimpan dalam RDBMS. Data Definistion Language (DDL) merupakan perintah dalam membuat atau merubah struktur objek database seperti create, alter, drop, truncate dan rename. Sedangkan Data Control Language (DCL) adalah perintah untuk mengatur hak ases user dalam database, seperti grand dan revoke. Sedangkan untuk Data Manipulation Language (DML) merupakan perintah untuk melakukan manipulasi data seperti menambah, menghapus, dan menubah data dalam table, misalkan insert, delete, update dan merge [3]. Data Manipulation Language (DML) adalah metode untuk melakukan query yang dapat dipergunakan apabila telah diciptakan, sehingga fungsi daripada query DML adalah melakukan manipulasi data yang telah dibuat dalam basis data [8].

$S Q L$ merupakan bahasa khusus yang dipergunakandalam melakukan akses dan melakukan pengelolaan RDBMS [3]. Fungsi date dalam melakukan DML dengan bahasa query merupakan fungsi yang dipergunakan bagi data, variable atau field yang berkaitan dengan data tanggal serta dapat juga diterapkan untuk data dari tanggal sistem komputer yang sedang aktif [9]. Fungsi tanggal dalam SQL meliputi fungsi DateAdd, Datelff, DatePart, DateName dan GetDate [6].

Berdasarkan penjelasan diatas, dalam penelitian ini akan dibahas tentang bagaimana membuat sintaks dengan bahasa SQL melalui sintaks query yang diimplementasikan dengan 
database Nilai Mahasiswa dengan menggunakan SQL Server 2008. Pada penelitian ini dibatasi pada 5 (lima) fungsi date yaitu DateAdd, Datelff, DatePart, DateName dan GetDate.

\section{Metode Penelitian}

Studi pustaka atau sering disebut literature review merupakan bagian dari karya tulis ilmiah yang memuat bahasan tentang penelitian terdahulu dan referensi ilmiah yang terkait dengan penelitian yang dijelaskan oleh penulis dalam karya tulis tersebut [10]. Kajian pustaka merupakan teori-teori pendukung yang melandasar masalah-masalah yang kita kaji serta membahas hasil-hasil riset sebelumnya yang telah dilakukan oleh orang lain dengan topik sejenis [11].

Database System Development Life Cycle (DSDLC) merupakan metode yang yang terdii dari tahapan melakukan perencanaan database, definisi sistem, analisis dan pengumpulan kebutuhan, peranvangan basis data, seleksi basis data, perancangan aplikasi, prototipe, implementasi, konversi data, pengujian dan pemeliharaan sistem yang telah dijalankan [12]. Pada pelaksanaaan penelitian ini dibatasi pada tahapan implementasi basis data menggunakan SQL Server 2008 dari diagram database sampai dengan melakukan uji query dengan memanfaatkan fungsi date yang meliputi DateAdd, Datelff, DatePart, DateName dan GetDate.

Berikut ini adalah kerangka pemikiran yang merupakan langkah-langkah yang dilakukan dalam mengimplementasikan query dari database Nilai Mahasiswa yang telah diimplementasi dengan memanfaatkan RDBMS Sql Server 2008.

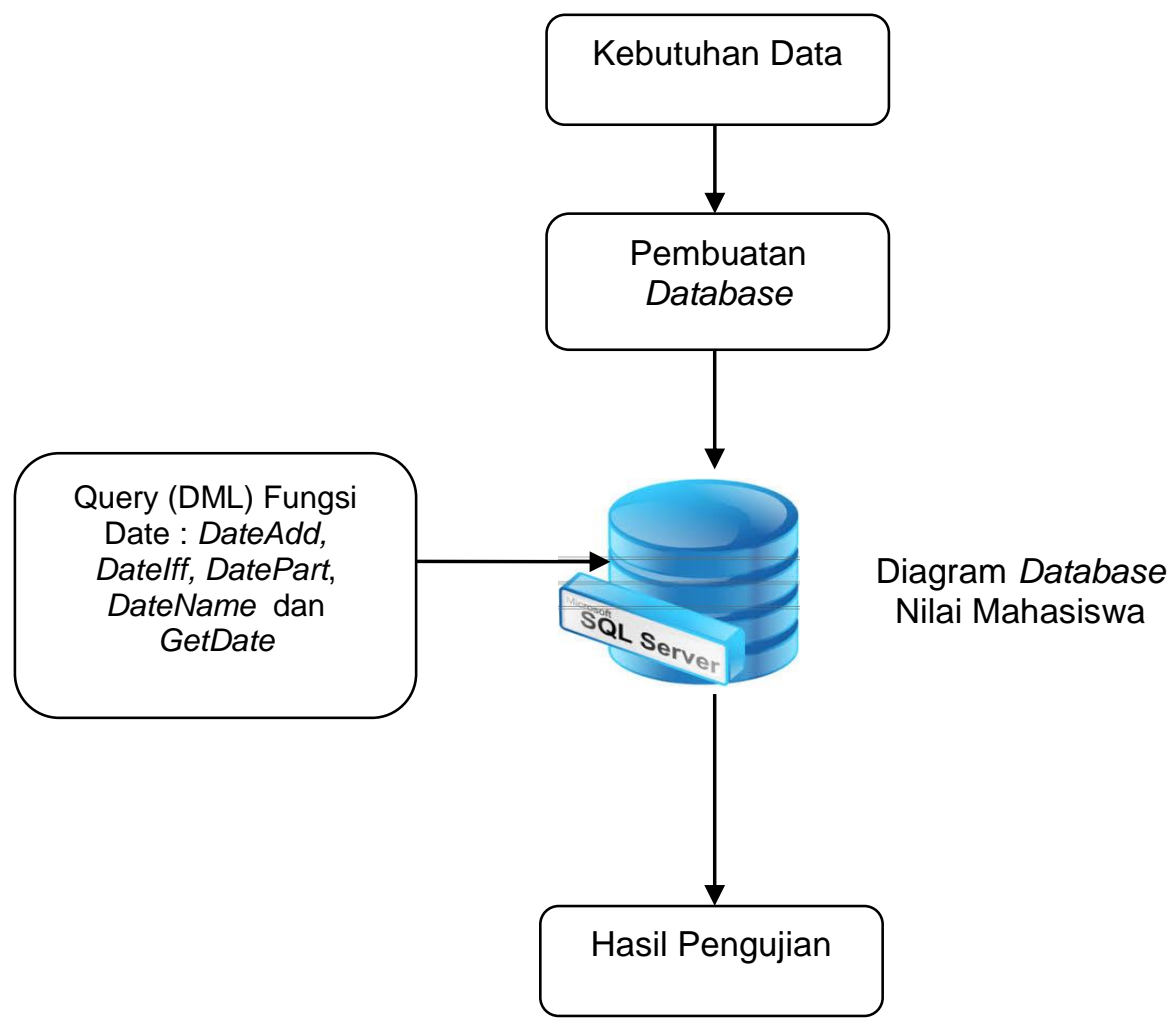

Sumber: Hasil Penelitian (2020)

\section{Gambar 1. Kerangka Pemikiran}

Penjelasan dari Gambar 1 tahapan awal yang dilakukan yaitu mendapatkan kebutuhan data dengan melakukan analisis untuk dilakukan perancangan basis data sampai terbentuk ERD dan struktur tabel-tabel. Selanjutnya dilakukan implementasi kedalam RDBMS Sql Server 2008 sampai terbentuk diagram dengan kasus database Nilai Mahasiswa. Berdasarkan diagram dan data yang telah ada dilakukan pengujian dengan sintaks query dari database Nilai 
Mahasiswa khususnya fungsi date untuk DateAdd, Datelff, DatePart, DateName dan GetDate menghasilkan informasi yang diingingkan.

\section{Hasil dan Pembahasan}

\subsection{Diagram Database}

Gambar 2 dibawah menunjukkan diagram database yang telah dibuat dengan menggunakan RDBMS Sql Server 2008 yang dimulai dari pembuatan database, pembuatan tabel, isi data, relasi sampai terbentuk diagram sebagai berikut:

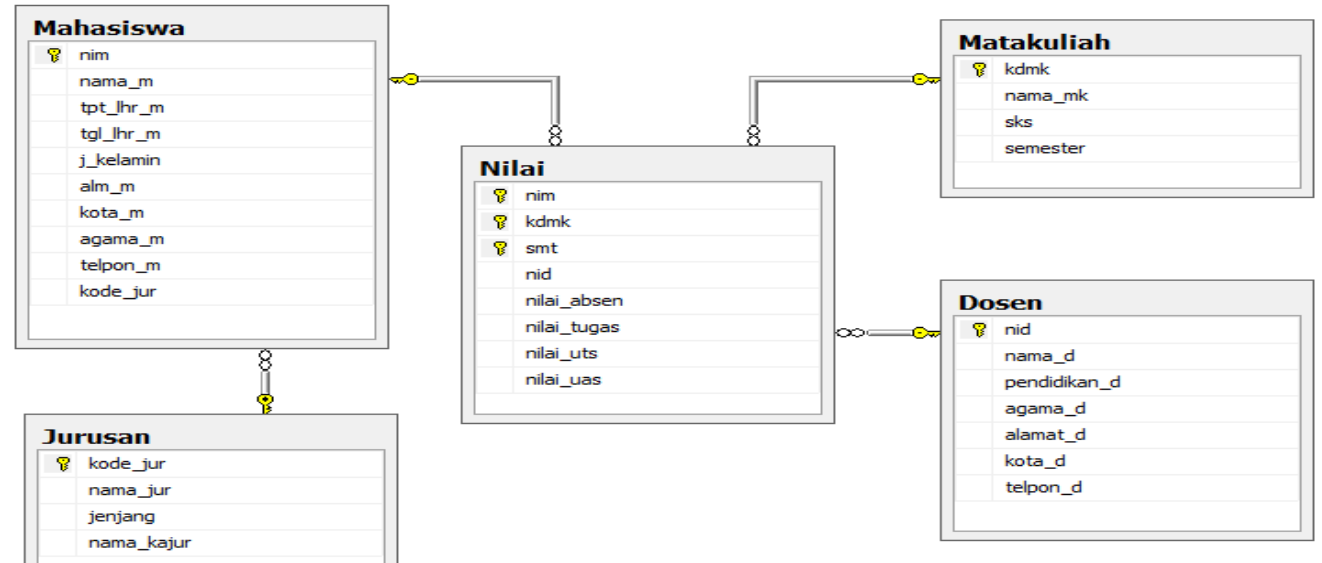

Sumber: Hasil Penelitian (2020)

Gambar 2. Diagram Nilai Mahasiswa

Pada diagram database Nilai Mahasiswa tersebut terdiri dari 5 (lima) tabel yaitu Mahasiswa, Jurusan, Nilai, Matakuliah dan Nilai. Relasi yang terjadi antar tabel terdiri dari 4 (empat) yaitu Jurusan ke Mahasiswa (one to many), Mahasiswa ke Nilai (one to many), Matakuliah ke Nilai (one to many) dan Dosen ke Nilai (one to many). Adapun isi data dari tabel jurusan, mahasiswa, nilai, matakuliah dan dosen seperti terlihat pada Gambar 3 berikut ini:

\begin{tabular}{|c|c|c|c|c|c|c|c|c|c|c|c|c|c|c|c|}
\hline & \multicolumn{3}{|c|}{ nama_d } & \multicolumn{2}{|c|}{ pendidikan_d } & \multicolumn{2}{|c|}{ agama_d } & \multicolumn{3}{|c|}{ alamat_d } & kota_d & telpon_d & & & \\
\hline 1 & D01 Amirn & \multicolumn{2}{|c|}{ Amir mahmud, SE } & \multicolumn{2}{|c|}{ S1 } & \multicolumn{2}{|c|}{ Islam } & \multicolumn{3}{|c|}{ JL. Nangka Permai No.17 } & Bekasi & $021-8712311$ & & & \\
\hline 2 & $\mathrm{D} 02$ & \multicolumn{2}{|c|}{ Susilo Wibowo,M.Kom. } & \multicolumn{2}{|l|}{ S2 } & \multicolumn{2}{|l|}{ Islam } & \multicolumn{3}{|c|}{ JL. Mambu Apus №.24 } & Bekasi & $021-8723122$ & & & \\
\hline \multirow[t]{2}{*}{3} & Tukin & \multicolumn{2}{|c|}{ Tukino Saputro, MM.SI. } & \multicolumn{2}{|l|}{ S2 } & \multicolumn{2}{|c|}{ Isllam } & \multicolumn{3}{|c|}{ JL. Indah Kelana II No.10 } & Cikarang & $021-8789991$ & & & \\
\hline & kode jur & \multicolumn{2}{|c|}{ nama_jur } & \multicolumn{2}{|c|}{ jenjang } & \multicolumn{4}{|c|}{ nama_kajur } & & & & & & \\
\hline 1 & KA & \multicolumn{2}{|c|}{ Komputerisasi Akutansi } & \multicolumn{2}{|c|}{ Diploma 3} & \multicolumn{4}{|c|}{ Rini Wulandari, MM, MMSi } & & & & & & \\
\hline 2 & MI & \multicolumn{2}{|c|}{ Manajemen Informatika } & \multicolumn{2}{|c|}{ Diploma 3} & \multicolumn{4}{|c|}{ Wahono Diprodjo, MM, MKom. } & & & & & & \\
\hline \multirow[t]{2}{*}{3} & SI & \multicolumn{2}{|c|}{ Sistem Informasi } & \multicolumn{2}{|c|}{ Strata 1} & \multicolumn{4}{|c|}{ Bagus Hermansyah, MM.Si,... } & & & & & & \\
\hline & nim & nama_m & \multicolumn{2}{|c|}{ tpt_lhr_m } & tgl_lhr__ & & & & j_kelamin & $\mathrm{alm}$ & & kota_m & agama_m & telpon_m & kode_jur \\
\hline 1 & 101031001 & Dewi Nurbaini & & kasi & $1987-1$ & $12-100$ & $0: 00: 0$ & 00.000 & Wanita & & Dahlia I Blok BC 2/3 & Bekasi Utara & Hindu & $021-8791290$ & $\mathrm{Tl}$ \\
\hline 2 & 101031002 & Deni Herma... & & karta & $1980-0$ & $01-170$ & $0: 00: 0$ & 00.000 & Pria & & Seruni Raya №.3 & Cikarang & Islam & $021-9897119$ & $\mathrm{Tl}$ \\
\hline 3 & 101031003 & Rini Hapsañ & Bog & gor & $1981-0$ & $08-180$ & $0: 00: 0$ & 00.000 & Wanita & & Cikarang Baru No.2 & Cikarang & Islam & $021-8911122$ & $\mathrm{Tl}$ \\
\hline & kdmk & nama_mk & & & & & & ks sem & nester & & & & & & \\
\hline 12 & MKK231206 & AKUTANSI D & DASAF & $R \|$ & & & 2 & 2 & & & & & & & \\
\hline 13 & MKK231213 & PENGANTAR & REKO & ONOMI & & & 2 & 1 & & & & & & & \\
\hline & nim & kdmk & smt & nid & nilai_at & bsen & nilai__ & tugas & nilai_uts & nilai_ua: & & & & & \\
\hline 12 & M01031... & MPK131201 & 1 & D02 & 14 & & 67 & & 78 & 87 & & & & & \\
\hline 13 & M01031... & MPK131203 & 1 & D05 & 11 & & 89 & & 90 & 90 & & & & & \\
\hline 14 & M01031... & MPK131204 & 2 & D01 & 10 & & 78 & & 90 & 76 & & & & & \\
\hline 15 & S010310... & MPK131201 & 1 & D02 & 14 & & 67 & & 54 & 78 & & & & & \\
\hline
\end{tabular}

Sumber : Hasil Penelitian (2020)

Gambar 3. Integrasi data database Nilai Mahasiswa 


\subsection{Implementasi Query}

Implementasi query dengan SQL Server 2008 yang akan dibuat adalah berdasarkan data-data yang ada pada database Nilai Mahasiswa seperti terlihat pada diagram Gambar 2. Fokus pembahasan dalam query ini adalah fungsi tanggal yang terdiri dari DateAdd, Datelff, DatePart, DateName dan GetDate. Fungsi dari tanggal adalah fungsi yang digunakan untuk data, variable atau column yang berhubungan dengan data tanggal. Beberapa fungsi tanggal yang akan digunakan dalam pembahasan ini dapat dilihat pada Tabel 1. berikut ini:

Tabel 1. Fungsi tanggal

\begin{tabular}{lll}
\hline Fungsi & Sintaks & Keterangan \\
\hline DATEADD & ( Datepart, number, Date) & $\begin{array}{l}\text { Melakukan penambahan datepart ke date yang } \\
\text { disesuikan besarnya number }\end{array}$ \\
\hline DATEDIFF & (Datepart, date, date2) & $\begin{array}{l}\text { Melakukan kalkulasi number datepart diantara dua } \\
\text { date }\end{array}$ \\
\hline DATEPART & (Datepart, date) & $\begin{array}{l}\text { Meremajakan datepart dari list date menjadi } \\
\text { integer }\end{array}$ \\
\hline DATENAME & (Datepart, date) & $\begin{array}{l}\text { Meremajakan datepart dari list date menjadi nilai } \\
\text { ASCl (misalkan October) }\end{array}$ \\
\hline GetDate & $(1)$ & Date dan Time saat ini \\
\hline SUmber $:$ Hasil Penelitian $(2020)$ &
\end{tabular}

Sumber : Hasil Penelitian (2020)

\section{Fungsi DateAdd}

Bentuk dari fungsi DateAdd ini adalah DateAdd(DatePart,Number,Date), yang merupakan fungsi yang bisa menambahkan datepart kedalam tanggal sesuai dengan besarnya number yang diberikan (DD,MM,YY).

Perintah query:

Tampilkan kolom nama_m,tgl_lhr_m, dan kolom '30 Hari Setelah Tanggal Lahir' dari tabel Mahasiswa dimana mahasiswa yang tempat lahirnya 'Bogor'

Query di SQL Server:

Select nama_m, tgl_lhr_m,'30 Hari Setelah Tanggal Lahir'=DATEADD(DD,30,tgl_lhr_m)

From Mahasiswa

Where tpt_Ihr_m='Bogor'

Dengan hasil query sebagai berikut:

nama_m tgl_lhr_m

Rini Hapsari 1981-08-18

30 Hari Setelah Tanggal Lahir

Lestary Ramiati

1976-01-10

1981-09-17

1976-02-09

Perintah query:

Tampilkan kolom nama_m,tpt_lhr_m, tgl_lhr_m, dan kolom '5 Bulan Setelah Tanggal Lahir' dari tabel Mahasiswa dimana mahasiswa yang tempat lahirnya 'Jakarta','Bogor'

Query di SQL:

Select nama_m, tpt_lhr_m, tgl_lhr_m,'5 Bulan Setelah Tanggal Lahir'=DATEADD

(MM,5,tgl_lhr_m)

From Mahasiswa

Where tpt_Ihr_m IN ('Jakarta','Bogor')

Dengan hasil query sebagai berikut:

$\begin{array}{llll}\text { nama_m } & \text { tpt_lhr_m } & \text { tgl_lhr_m } & \text { 5 Bulan Setelah Tanggal Lahir } \\ \text { Deni Hermawan } & \text { Jakarta } & 1980-01-17 & 1980-06-17 \\ \text { Rini Hapsari } & \text { Bogor } & 1981-08-18 & 1982-01-18 \\ \text { Susilo Wahono } & \text { Jakarta } & 1979-12-21 & 1980-05-21 \\ \text { Lestary Ramiati } & \text { Bogor } & 1976-01-10 & 1976-06-10 \\ \text { Muhammad F. } & \text { Jakarta } & 1980-10-13 & 1981-03-13 \\ \text { Yuni Nurwati } & \text { Jakarta } & 1978-11-14 & 1979-04-14\end{array}$


Perintah query:

Tampilkan kolom nama_m,tpt_lr_m,tgl_lhr_m, dan kolom '5 Tahun Setelah Tanggal Lahir' dari tabel Mahasiswa dimana mahasiswa yang tempat lahirnya 'Jakarta','Bekasi'

Query di SQL Server:

Select nama_m, tpt_lhr_m,tgl_lhr_m,'5 Tahun Setelah Tanggal Lahir'= DATEADD

(YY,5,tgl_lhr_m)

From Mahasiswa

Where tpt_lhr_m IN ('Jakarta','Bekasi')

Dengan hasil query sebagai berikut:

$\begin{array}{llll}\text { nama_m } & \text { tpt_lhr_m } & \text { tgl_lhr_m } & \text { 5 Tahun Setelah Tanggal Lahir } \\ \text { Dewi Nurbaini } & \text { Bekasi } & 1987-12-10 & 1992-12-10 \\ \text { Deni Hermawan } & \text { Jakarta } & 1980-01-17 & 1985-01-17 \\ \text { Susilo Wahono } & \text { Jakarta } & 1979-12-21 & 1984-12-21 \\ \text { Yonita Veronika } & \text { Bekasi } & 1980-10-24 & 1985-10-24 \\ \text { Ira Sulistyaningsih } & \text { Bekasi } & 1979-12-01 & 1984-12-01 \\ \text { Fitria Choirunissa } & \text { Bekasi } & 1979-01-21 & 1984-01-21 \\ \text { Muhammad F. } & \text { Jakarta } & 1980-10-13 & 1985-10-13 \\ \text { Yuni Nurwati } & \text { Jakarta } & 1978-11-14 & 1983-11-14\end{array}$

\section{Fungsi DatellF}

Bentuk dari fungsi DatelFF ini adalah DateDIFF(DatePart,Date,Date2), merupakan fungsi yang menjalankan kalkulasi angka datepart antara dua tanggal yang diberikaan (DD,MM,YY).

Perintah query:

Tampilkan kolom nama_m,tpt_lhr_m,tgl_lhr_m, 'Tanggal dan Waktu Sekarang', 'Jumlah Hari' dari tabel Mahasiswa dimana mahasiswa yang tempat lahirnya 'Jakarta'

Query di SQL Server

Select nama_m, tpt_lhr_m,tgl_lhr_m,getdate() 'Tanggal dan Waktu Sekarang',"Jumlah

Hari"=DATEDIFF (DD,tgl_Ihr_m,getdate())

From Mahasiswa

Where tpt_Ihr_m='Jakarta'

Dengan hasil query sebagai berikut:

nama m

Deni Hermawan Jakarta 1980-01-17

Tanggal dan Waktu Sekarang Jumlah Hari

Susilo Wahono

Jakarta 1979-12-21

2020-06-23 15:58:40.050

14768

Muhammad F.

2020-06-23 15:58:40.050

14795

Jakarta 1980-10-13

2020-06-23 15:58:40.050

14498

Yuni Nurwati

Jakarta 1978-11-14

2020-06-23 15:58:40.050

15197

Perintah query:

Tampilkan kolom nama_m,tgl_Ihr_m, 'Tanggal dan Waktu Sekarang', 'Jumlah Bulan' dari table Mahasiswa, dimana mahasiswa yang tempat lahirnya 'Jakarta'

Query di SQL Server :

Select nama_m, tpt_lhr_m, tgl_lhr_m,getdate() 'Tanggal dan Waktu Sekarang','Jumlah Bulan' $=$ DATEDIFF $\left(\mathrm{mm}, \mathrm{tgl} \_\mathrm{lhr} \_\mathrm{m}, \mathrm{get}\right.$ date ()$)$

From Mahasiswa

Where tpt_lhr_m='Jakarta'

Dengan hasil query sebagai berikut:

Nama_m tpt_lhr_m

Deni Hermawan Jakarta 1980-01-17

Tanggal dan Waktu Sekarang Jumlah Bulan

Susilo Wahono

Jakarta 1979-12-21

2020-06-23 16:00:47.387

485

Muhammad F,i

Jakarta 1980-10-13

2020-06-23 16:00:47.387 486

2020-06-23 16:00:47.387 476 
Perintah query:

Tampilkan kolom nama_m,tgl_Ihr_m, 'Tanggal dan Waktu Sekarang', 'Jumlah Tahun' dari table Mahasiswa dimana mahasiswa yang tempat lahirnya 'Jakarta'

Query di SQL Server:

Select nama_m, tpt_lhr_m, tgl_lhr_m,getdate() 'Tanggal dan Waktu Sekarang','Jumlah

Tahun'=DATEDDIFF (yy,tgl_lhr_m,getdate())

From Mahasiswa

Where tpt_Ihr_m='Jakarta'

Dengan hasil query sebagai berikut:

\section{nama_m tpt_lhr_m}

Deni Hermawan

Jakarta 1980-01-17

Tanggal dan Waktu Sekarang 2020-06-23 16:01:53.030

Jumlah Tahun

Susilo Wahono

Jakarta 1979-12-21

2020-06-23 16:01:53.030

40

Muhammad F.

Jakarta 1980-10-13

2020-06-23 16:01:53.030

41

Yuni Nurwati

\section{Fungsi DatePart}

Bentuk dari fungsi DatePart ini adalah DatePart (DatePart,Date), adalah fungsi untuk mengembalikan datepart dari list tanggal dalam bentuk integer sesuai tanggal yang disampaikan (DD,MM,YY).

Perintah query:

Tampilkan kolom nama_m, tpt_lhr_m, tgl_lhr_m, 'Tanggal Lahir' dari table Mahasiswa dimana mahasiswa yang tempat lahirnya 'Bogor' dan 'Jakarta'

Query di SQL Server:

Select nama_m, tpt_lhr_m, tgl_lhr_m, 'Tanggal Lahir'=DATEPART(DD,tgl_lhr_m)

From Mahasiswa

Where tpt_Ihr_m IN ('Bogor','Jakarta')

Dengan hasil query sebagai berikut:

$\begin{array}{llll}\text { nama_m } & \text { tpt_lhr_m } & \text { tgl_lhr_m } & \text { Tanggal Lahir } \\ \text { Deni Hermawan } & \text { Jakarta } & 1980-01-17 & 17 \\ \text { Rini Hapsari } & \text { Bogor } & 1981-08-18 & 18 \\ \text { Susilo Wahono } & \text { Jakarta } & 1979-12-21 & 21 \\ \text { Lestary Ramiati } & \text { Bogor } & 1976-01-10 & 10 \\ \text { Muhammad F.i } & \text { Jakarta } & 1980-10-13 & 13 \\ \text { Yuni Nurwati } & \text { Jakarta } & 1978-11-14 & 14\end{array}$

Perintah query:

Tampilkan kolom nama_m,tgl_lhr_m, 'Bulan Lahir' dari table Mahasiswa dimana mahasiswa yang tempat lahirnya 'Bogor' dan 'Bekasi'

Query di SQL Server:

SELECT nama_m, tpt_lhr_m,tgl_lhr_m,'Bulan Lahir'=DATEPART (mm,tgl_lhr_m)

FROM Mahasiswa

Where tpt_lhr_m IN ('Bogor','Bekasi')

Dengan hasil query sebagai berikut:

$\begin{array}{llll}\text { Nama_m } & \text { tpt_lhr_m } & \text { tgl_lhr_m } & \text { Bulan Lahir } \\ \text { Dewi Nurbaini } & \text { Bekasi } & 1987-12-10 & 12 \\ \text { Rini Hapsari } & \text { Bogor } & 1981-08-18 & 8 \\ \text { Yonita Veronika } & \text { Bekasi } & 1980-10-24 & 10 \\ \text { Lestary Ramiati } & \text { Bogor } & 1976-01-10 & 1\end{array}$




$\begin{array}{llll}\text { Ira Sulistyaningsih } & \text { Bekasi } & 1979-12-01 & 12 \\ \text { Fitria Choirunissa } & \text { Bekasi } & 1979-01-21 & 1\end{array}$

Perintah query:

Tampilkan kolom nama_m,tgl_lhr_m, 'Tahun Lahir' dari table Mahasiswa dimana mahasiswa yang tempat lahirnya 'Bogor', 'Surabaya' dan 'Solo'.

Query di SQL Server:

SELECT nama_m, tpt_lhr_m, tgl_Ihr_m,'Tahun Lahir'=DATEPART (yy,tgl_lhr_m)

FROM Mahasiswa

Where tpt_lhr_m IN ('Bogor','Surabaya','Solo')

Dengan hasil query sebagai berikut:

$\begin{array}{llll}\text { Nama_m } & \text { tpt_lhr_m } & \text { tgl_lhr_m } & \text { Tahun Lahir } \\ \text { Rini Hapsari } & \text { Bogor } & 1981-08-18 & 1981 \\ \text { Ahmad Sofyan } & \text { Surabaya } & 1977-02-13 & 1977 \\ \text { Daffa Alrozak } & \text { Solo } & 1978-10-10 & 1978 \\ \text { Lestary Ramiati } & \text { Bogor } & 1976-01-10 & 1976\end{array}$

\section{Fungsi DateName}

Bentuk dari fungsi DateName ini adalah DateName(DatePart,Date), adalah fungsi yang mengembalikan datepart dari list tanggal kedalam nilai ASCII (misal October), fungsi ini hanya dalam bentuk bulan (MM).

Perintah query:

Tampilkan kolom nama_m,tpt_lhr_m, tgl_lhr_m, 'Nama Bulan Lahir' dari table Mahasiswa dimana mahasiswa yang tempat lahirnya 'Jakarta'

Query di SQL Server:

Select nama_m, tpt_lhr_m, tgl_lhr_m, 'Nama Bulan Lahir'=DATENAME(mm,tgl_lhr_m)

From Mahasiswa

Where tpt_Ihr_m='Jakarta'

Dengan hasil query sebagai berikut:

$\begin{array}{llll}\text { Nama_m } & \text { tpt_lhr_m } & \text { tgl_lhr_m } & \text { Nama Bulan Lahir } \\ \text { Deni Hermawan } & \text { Jakarta } & 1980-01-17 & \text { January } \\ \text { Susilo Wahono } & \text { Jakarta } & 1979-12-21 & \text { December } \\ \text { Muhammad F. } & \text { Jakarta } & 1980-10-13 & \text { October } \\ \text { Yuni Nurwati } & \text { Jakarta } & 1978-11-14 & \text { November }\end{array}$

\section{Fungsi GetDate}

Bentuk dari fungsi GetDate ini adalah GetDate(), adalah fungsi yang digunakan untuk mengetahui tanggal dan waktu sekarang.

Perintah query:

Tampilkan kolom 'Tanggal Hari Ini' dan '15 Hari Dari Sekarang'

Query di SQL Server:

Select 'Tanggal Hari Ini'=GetDate(),'15 Hari Dari Sekarang'=Getdate()+5

Dengan hasil query sebagai berikut:

Tanggal Hari Ini

2020-06-23 16:21:20.767

15 Hari Dari Sekarang

2020-06-28 16:21:20.767 
Berdasarkan fungsi date untuk DateAdd, Datelff, DatePart, DateName dan GetDate menghasilkan informasi dengan menggunakan SQL Server 2008, berikut ini pemetaan dari perintah query dan sintaks sql nya:

Tabel 2. Perintah query dan hasil implementasi dengan SQL Server 2008

\begin{tabular}{|c|c|c|}
\hline Operasi & Perintah Query & SQL Server 2008 \\
\hline \multirow[t]{3}{*}{ DateAdd } & $\begin{array}{l}\text { Tampilkan kolom nama_m,tgl_lhr_m, dan } \\
\text { kolom '30 Hari Setelah Tanggal Lahir' dari } \\
\text { tabel Mahasiswa dimana mahasiswa yang } \\
\text { tempat lahirnya 'Bogor' }\end{array}$ & $\begin{array}{l}\text { Select nama_m, tgl_Ihr_m,'30 Hari Setelah } \\
\text { Tanggal Lahir'=DATEADD }\left(D D, 30, t g I / I h r \_m\right) \\
\text { From Mahasiswa } \\
\text { Where tpt_lhr_m='Bogor' }\end{array}$ \\
\hline & $\begin{array}{l}\text { Tampilkan kolom nama_m,tptlhr_m, } \\
\text { tgl_lhr_m, dan kolom '5 Bulan Setelah } \\
\text { Tanggal Lahir' dari tabel Mahasiswa dimana } \\
\text { mahasiswa yang tempat lahirnya } \\
\text { 'Jakarta','Bogor' }\end{array}$ & $\begin{array}{l}\text { Select nama_m, tpt_Ihr_m, tgl_Ihr_m,'5 Bulan } \\
\text { Setelah Tanggal Lahir'=DATEADD } \\
\text { (MM,5,tgl_Ihr_m) } \\
\text { From Mahasiswa } \\
\text { Where tpt_Ihr_m IN ('Jakarta','Bogor') }\end{array}$ \\
\hline & $\begin{array}{l}\text { Tampilkan kolom nama_m,tpt_lr_m, } \\
\text { tgl_Ihr_m, dan kolom '5 Tahun Setelah } \\
\text { Tanggal Lahir' dari tabel Mahasiswa dimana } \\
\text { mahasiswa yang tempat lahirnya } \\
\text { 'Jakarta','Bekasi' }\end{array}$ & $\begin{array}{l}\text { Select nama_m, tpt_Ihr_m,tgl_Ihr_m,'5 Tahun } \\
\text { Setelah Tanggal Lahir'=DATEADD } \\
\text { (YY,5,tgl_Ihr_m) } \\
\text { From Mahasiswa } \\
\text { Where tpt_Ihr_m IN ('Jakarta','Bekasi') }\end{array}$ \\
\hline \multirow[t]{3}{*}{ DatellF } & $\begin{array}{l}\text { Tampilkan kolom nama_m,tpt_lhr_m, } \\
\text { tgl_lhr_m, 'Tanggal dan Waktu Sekarang', } \\
\text { 'Jumlah Hari' dari tabel Mahasiswa dimana } \\
\text { mahasiswa yang tempat lahirnya 'Jakarta' }\end{array}$ & $\begin{array}{l}\text { Select nama_m, tpt_Ihr_m,tgl_Ihr_m,getdate() } \\
\text { 'Tanggal dan Waktu Sekarang',"Jumlah } \\
\text { Hari"=DATEDIFF (DD,tgl_Ihr_m,getdate()) } \\
\text { From Mahasiswa } \\
\text { Where tpt_Ihr_m='Jakarta' }\end{array}$ \\
\hline & $\begin{array}{l}\text { Tampilkan kolom nama_m,tgl_lhr_m, } \\
\text { 'Tanggal dan Waktu Sekarang', 'Jumlah } \\
\text { Bulan' dari table Mahasiswa, dimana } \\
\text { mahasiswa yang tempat lahirnya 'Jakarta' }\end{array}$ & $\begin{array}{l}\text { Select nama_m, tpt_Ihr_m, tgl_Ihr_m,getdate() } \\
\text { 'Tanggal dan Waktu Sekarang','Jumlah Bulan' } \\
\text { =DATEDIFF (mm,tgl_Ihr_m,getdate()) } \\
\text { From Mahasiswa } \\
\text { Where tpt_Ihr_m='Jakarta' }\end{array}$ \\
\hline & $\begin{array}{l}\text { Tampilkan kolom nama_m,tgl_lhr_m, } \\
\text { 'Tanggal dan Waktu Sekarang', 'Jumlah } \\
\text { Tahun' dari table Mahasiswa dimana } \\
\text { mahasiswa yang tempat lahirnya 'Jakarta' }\end{array}$ & $\begin{array}{l}\text { Select nama_m, tpt_Ihr_m, tgl_Ihr_m,getdate() } \\
\text { 'Tanggal dan Waktu Sekarang','Jumlah } \\
\text { Tahun'=DATEDIFF (yy,tgl_Ihr_m,getdate()) } \\
\text { From Mahasiswa } \\
\text { Where tpt_Ihr_m='Jakarta' }\end{array}$ \\
\hline \multirow[t]{3}{*}{ DatePart } & 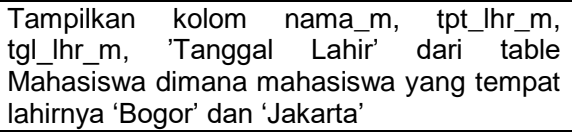 & $\begin{array}{l}\text { Select nama_m, tpt_Ihr_m, tgl_Ihr_m, 'Tanggal } \\
\text { Lahir'=DATEPART(DD,tgl_Ihr_m) } \\
\text { From Mahasiswa } \\
\text { Where tpt_lhr_m IN ('Bogor','Jakarta') }\end{array}$ \\
\hline & $\begin{array}{l}\text { Tampilkan kolom nama_m,tgl_lhr_m, 'Bulan } \\
\text { Lahir' dari table Mahasiswa dimana } \\
\text { mahasiswa yang tempat lahirnya 'Bogor' dan } \\
\text { 'Bekasi' }\end{array}$ & $\begin{array}{l}\text { SELECT nama_m, tpt_lhr_m,tgl_Ihr_m, 'Bulan } \\
\text { Lahir'=DATEPART (mm,tgl_Ihr_m) } \\
\text { FROM Mahasiswa } \\
\text { Where tpt_Ihr_m IN ('Bogor','Bekasi') }\end{array}$ \\
\hline & $\begin{array}{l}\text { Tampilkan kolom nama_m,tgl_lhr_m, } \\
\text { 'Tahun Lahir' dari table Mahasiswa dimana } \\
\text { mahasiswa yang tempat lahirnya 'Bogor', } \\
\text { 'Surabaya' dan 'Solo'. }\end{array}$ & $\begin{array}{l}\text { SELECT nama_m, tpt_Ihr_m, tgl_Ihr_m,'Tahun } \\
\text { Lahir'=DATEPART (yy,tgI_Ihr_m) } \\
\text { FROM Mahasiswa } \\
\text { Where tpt_Ihr_m IN ('Bogor','Surabaya', 'Solo') }\end{array}$ \\
\hline DateName & $\begin{array}{l}\text { Tampilkan kolom nama_m,tpt_lhr_m, } \\
\text { tgl_Ihr_m, 'Nama Bulan Lahir' dari table } \\
\text { Mahasiswa dimana mahasiswa yang tempat } \\
\text { lahirnya 'Jakarta' }\end{array}$ & $\begin{array}{l}\text { Select nama_m, tpt_Ihr_m, tgl_Ihr_m, 'Nama } \\
\text { Bulan Lahir'=DATENAME(mm,tgI_Ihr_m) } \\
\text { From Mahasiswa } \\
\text { Where tpt_Ihr_m='Jakarta' }\end{array}$ \\
\hline
\end{tabular}

Sumber : Hasil Penelitian (2020)

\section{Kesimpulan}

Berdasarkan hasil uji coba dari operasi date implementasi SQL dari database Nilai Mahasiswa dapat disimpulkan sebagai berikut: 1). Operasi date yang digunakan dalam implementasi query terdiri dari fungsi DateAdd, Datelff, DatePart, DateName dan GetDate 2). Database untuk melakukan uji terhadap operasi-operasi fungsi date dengan menggunakan database Nilai Mahasiswa dengan menggunakan RDBMS SQL Server 2008 3). Sintaks SQL yang digunakan untuk melakukan uji adalah dengan menggunakan DML pada editor SQL Server 2008 untuk fungsi DateAdd, Datelff, DatePart, DateName dan GetDate.

\section{Referensi}

[1] Y. Y. Joefrie and P. P. Kalatiku, "Desain Basis Data Sistem Informasi Akademik Di 
Fakultas Teknik Universitas Tadulako," J. IImial Foristek, vol. 2, no. 21, pp. 190-194, 2012.

[2] D. P. P. Meidi and K. K. Purnamasari, "Penerjemah Teks Bahasa Indonesia Ke Dalam Dml ( Data Manipulation Language )," 2019.

[3] D. Setiyadi, Sistem Basis Data dan SQL (Structured Query Language). Bogor: Mitra Macana Media, 2020.

[4] R. R. Rerung, Pemrogaman Web Dasar. Yogyakarta: Deepublish, 2018.

[5] K. Wahana, SQL Server 2012. Yogyakarta: Andi, 2013.

[6] D. Setiyadi and D. Abdullah, Mudah dan Cepat Belajar Database dengan SQL Server 2008. Lhokseumawe: Sefa Bumi Persada, 2020.

[7] M. Nuryana and Sulistiyono, "Analisa dan Perancangan Sistem Front Office Hotel Bidakara Serang," Protekinfo, vol. 1, no. September, pp. 1-5, 2014.

[8] C. A. Pamungkas, Pengantar dan Implementasi Basis Data. Yogyakarta: Deepublish, 2017.

[9] A. Nugroho, Mengembangkan Aplikasi Basis Data Menggunakan C\#+SQL Server. Yogyakarta: Andi, 2010.

[10] I. Hermawan, Metodologi Penelitian Pendidikan, Kuantitatif, Kualitatif dan Mixed Methode. Kuningan: Hidayatul Quran Kuningan, 2019.

[11] R. Fiva, Pintar Menulis Karangan IImiah, Kunci Sukses Dalam Menulis IImiah. Yogyakarta: Andi, 2010.

[12] Indrajani, Database Design All in One (Theory, Practice and Case Study). Jakarta: PT Elex Media Komputindo, 2018. 